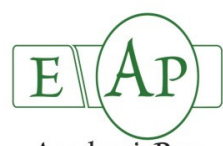

AcademicPres

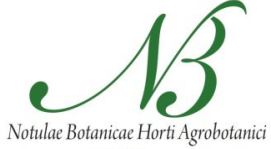

Cluj-Napoca

\title{
Total Antioxidant Capacity and Total Phenolics Content of Phyllostachys Taxa Shoots
}

\author{
András NEMÉNYI ${ }^{1}$,Éva STEFANOVITSNÉ-BÁNYAI²,Zoltán PÉK ${ }^{1}$, Attila HEGEDÜS³ \\ Csaba GYURICZA ${ }^{4}$, Zoltán BARÓCSI ${ }^{1 *}$, Lajos HELYES ${ }^{1}$ \\ ${ }^{I}$ Szent István University, Faculty of Agricultural and Environmental Sciences, Institute of Horticulture, Páter K. u. 1, Gödöllo", 2100 Hungary; \\ nemenyi.andras@mkk.szie.hu;pek.zoltan@mkk.szie.hu;barocsi.zoltan@mkk.szie.hu(“correspondingauthor);helyes.lajos@mkk.szie.hu \\ ${ }^{2}$ Corvinus University of Budapest, Faculty of Food Science, Department of Applied Chemistry, Villanyi ut 6470, Budapest, 1118 Hungary; eva.banyai@uni-corvinus.bu \\ ${ }^{3}$ Corvinus University of Budapest, Faculty of Horticultural Science, Department of Genetics and Plant Breeding, \\ Villányi út6470,Budapest, 1118 Hungary; hegedus.attila@uni-corvinus.hu \\ ${ }^{4}$ Szent István University, Faculty of Agricultural and Environmental Sciences, Institute of Plant Production, \\ PáterK.u.1, Gödölló, 2100Hungary;gyuricza.csaba@mkk.szie.bu
}

\begin{abstract}
Total phenolic content (TP) and total antioxidant capacity (AC) were analysed in shoots of Phyllostachys aureosulcata (PA), P aureosulcata f. aureocaulis (PAA), P. aureosulcata f. spectabilis (PAS), P. bissetii (PB), P. flexuosa (PF), P. humilis (PH), $P$. iridescens (PI), P. nigra var. nigra (PNN), P. nigra var. henonis (PNH), P. mannii (PM), P. sulphurea var. sulphurea (PSS), $P$. violascens (PVI), P. viridiglaucescens (PVG), P. vivax $\mathrm{f}$. aureocaulis (PVA), collected on four harvest dates. Both $\mathrm{TP}$ and AC were determined following three processing methods, fresh, boiled and pickled in shoots of PF. Comparative study of TP and AC in the above Phyllostachys species shoots has not been reported before. The highest TP $(1,227.6 \mu \mathrm{g} \mathrm{GA} / \mathrm{ml})$ and AC $(154.0$ $\mu \mathrm{g} \mathrm{AA} / \mathrm{ml}$ ) values were measured in fresh shoots and the lowest in pickled ones. The highest values of TP were measured in the case of PA (1,321.95 $\mu \mathrm{g} \mathrm{GA} / \mathrm{ml})$. The other taxa followed in decreasing order: PF, PVI, PI, PAA, PB, PAS, PNN, PNH, PM, PH, PSS and PVA. The highest AC values were obtained in the case of PI $(184.24 \mu \mathrm{g} \mathrm{AA} / \mathrm{ml})$. The other taxa followed in decreasing order: PA, PF, PSS, PNN, PNH, PVG, PB, PAA, PAS, PV, PVA, PM and PH. The highest TP values were measured in taxa harvested on the first collection date and the values consequently decreased in taxa collected at later harvest dates. Our findings suggest that the earlier harvest date, through the influence of lower temperatures, could enhance the phytochemical content of bamboo shoots.
\end{abstract}

Keywords: bamboo, Bambusoideae, olericulture, Poaceae, vegetable

\section{Introduction}

Phyllostachys species are temperate bamboos of Poaceae, Bambusoideae, Shibataeinae, predominantly native of subtropical to warm temperate areas of China and have long been introduced to Korea (Ohrnberger, 2002). Phyllostachys species are of great agricultural importance in the Far East, primarily in forestry, as the culms are used in wood industry (Kleinhenz and Midmore, 2001) and harvested when developing young shoots for fresh market or processed vegetables (Chongtham et al., 2011; Choudry et al., 2012). Because of their aesthetic qualities, they are also planted in gardens and parks as ornamentals (Ohrnberger, 2002).

Bamboos have long been used in Chinese and Korean traditional medical pharmacology (Hong et al., 2010). Bamboo shoots contain dietary fiber (Park and Jhon, 2009), protein, carbohydrates, amino acids, minerals (Chongtham et al, 2011), flavonoids, phenolic compounds (Park and Jhon, 2010) and sterols (Lu et al., 2009). Shoot or culm extracts showed high antioxidant (Choi et al., 2008; Lee et al., 2008; Li et al., 2013), anti-inflamatory (Chae et al., 2010; Park and Lee, 2012), antihypertensive (Kim et al., 2008), antibacterial (Kim et al., 2011) and anti-malassezia (Lee et al., 2010) properties. Shoot or culm extracts have also been shown to have immuno-stimulating (Kweon et al., 2003), anticarcinogenic properties (Lu et al., 2010) and also anti-apoptic effects in ischemic injury treatment (Hong et al., 2010). Other beneficial health effects include the use as a source of dietary fiber for improving lipid profile and bowel function (Park and Jhon, 2009), as a therapeutic agent for 
atopic dermatitis (Qi et al., 2009) and against allergic airway diseases including asthma ( $\mathrm{Ra}$ et al., 2010). It also has been used for the prevention of hypercholesterolemia (Cho et al., 2009; Ham et al., 2009), high blood pressure, pulmonary inflammation and lung injury (Chae et al., 2010) and to relieve lipotoxicity (Cho et al., 2009). The study of Kim et al. (2012) has evaluated the nutritional components and antioxidant activities of ojuk (Phyllostachys nigra) shoot and leaf water extracts prepared by traditional tea manufacturing processes compared with green or mate tea. Their results indicated that the ABTS and DPPH free radical scavenging activities of shoot tea was seven fold higher compared to green or mate tea. Zhang et al. (2011) has compared the effects of different cooking methods on antioxidant activity and nutrient components in Phyllostachys praecox shoots. They found that compared to the traditional boiling, stir-frying or steaming did not decrease the antioxidant capacities or total phenolic content of bamboo shoots. The measured differences in total phenolic content were not significant. Yoo and Chung (1999) examined the changes in chemical properties of bamboo shoots during the manufacture of pickles. They measured significantly lower moisture, crude protein and fat, tannin and ascorbic acid content in the bamboo shoot pickles. Kim et al. (2012) studied the shelf-life of pickles processed from maengiong bamboo (Phyllostachys pubescens). High temperatures $\left(35^{\circ}\right.$ or $45^{\circ} \mathrm{C}$ ) had a negative effect on sensory characteristics, while shelf-life at $20^{\circ} \mathrm{C}$ was determined to be 14 months.

The present study aimed to investigate the total phenolics content and antioxidant activity of different edible Phyllostachys bamboo taxa shoots, including the effect of three preparation methods, namely fresh, boiled or pickled shoots.

\section{Materials and methods}

Plantmaterial and samplepreparation

Five shoots per each sample of similar size, diameter and position under the canopy were randomly collected when they emerged from the soil surface on four harvest dates in 2011. The following 14 Phyllostachys taxa were collected: on $22^{\text {nd }}$ of April: $P$. aureosulcata $(\mathrm{PA}), P$. flexuosa $(\mathrm{PF}), P$. iridescens $(\mathrm{PI}), P$. violascens (PVI), on $29^{\text {th }}$ of April: $P$ aureosulcata $\mathrm{f}$ aureocaulis (PAA), $P$. aureosulcata f. spectabilis (PAS), P. bissetii (PB), P. viridiglancescens (PVG), on the $13^{\text {th }}$ of May: P. humilis (PH), P. nigra var. nigra (PNN), P. nigra var. henonis (PNH), P. mannii (PM), and on the $27^{\text {th }}$ of May: $P$. sulphurea var. sulphurea (PSS), $P$. vivax $f$. aureocaulis (PVA), plants growing in the Botanical Garden of Szent István University, Gödöllö (4735'38” N latitude, 19²2’09" E longitude and $242 \mathrm{~m}$ altitude). Samples were collected in four repetitions per taxa.

\section{Processing of Phyllostachysshoots}

The collected shoots were washed, the culm sheaths were removed and the remaining shoots were cut into small pieces and grounded. $5 \mathrm{~g}$ of samples were infused with $100 \mathrm{ml}$ of boiling water. The aqueous extracts were stored at room temperature for $24 \mathrm{~h}$. After centrifugation $(13,000 \mathrm{rpm}, 10 \mathrm{~min})$ the supernatant was stored in a refrigerator at $-20^{\circ} \mathrm{C}$, for 48 hours, until the analyses. For the comparison of fresh shoots with boiled and pickled shoots, the above procedure was also carried out in the case of boiled (10 min at $100^{\circ} \mathrm{C}$ water temperature) or pickled (boiled for $10 \mathrm{~min}$ in a mixture of $200 \mathrm{ml} 20 \%$ acetic acid, $200 \mathrm{~g}$ sodium chloride, $400 \mathrm{~g}$ saccharose and $500 \mathrm{ml}$ of water, placed in glass vessels sealed with lids and gradually allowed to cool) shoots of $P$. flexuosa.

\section{Determination of total phenolics content}

The total amount of soluble phenols (TP) was determined using Folin-Ciocalteu's reagent according to the method of Singleton and Rossi (1965) and determined spectrophotometrically at $760 \mathrm{~nm}$. The content of soluble phenols was calculated from a standard curve obtained by different concentrations of gallic acid (GA) and given in $\mu \mathrm{g} \mathrm{GA} / \mathrm{ml}$.

\section{Determination of total antioxidant capacity by FRAP assay}

The total antioxidant capacity (AC) related to ascorbic acid was determined spectrophotometrically using the FRAP (Ferric Reducing Antioxidant Power) method according to Benzie and Strain (1996). It is based on the reduction of the $\mathrm{Fe}^{3+}-\mathrm{TPTZ}$ complex to the ferrous form at low $\mathrm{pH}$. This reduction was monitored by measuring the absorption change at $593 \mathrm{~nm}$. Results were expressed as $\mu$ gequivalents of ascorbic acid (AA).

\section{Measurement of environmental parameters and irrigation}

Air temperature $\left({ }^{\circ} \mathrm{C}\right)$ and precipitation $(\mathrm{mm})$ were recorded during the course of the experiment. Air temperature was measured six times per hour by a meteorological instrument. Potential evapotranspiration $\left(\mathrm{ET}_{0}\right)$ was calculated according to Helyes and Varga (1994) and Helyes et al. (2013) for other vegetable crops; the amount of daily water demand was calculated based on weather forecasting data of the Hungarian Meteorological Service (http://www.met.hu/idojaras/elorejelzes) from daily average temperature (in ${ }^{\circ} \mathrm{C}$ ) divided by five and was expressed in millimetre:

Every week temperature averaged over 2-3 day intervals was used to calculate the daily potential evapotranspiration $\left(\mathrm{ET}_{0}\right)$. The amount of irrigation was calculated by $\mathrm{ET}_{0}$ for the

$$
I_{d}=\left(\frac{T_{\min }+T_{\max }}{2}\right) / 5
$$

forecasting period corrected by the amount of precipitation. If precipitation covered the irrigation demand until the next irrigation date there was no irrigation, but if it was less than irrigation demand, the respective amount of $\mathrm{ET}_{0}$ was supplied. Irrigation was given by overhead sprinklers from April $1^{\text {st }}$ till the end of October by the calculated amount of water on every Monday, Wednesday and Friday morning.

\section{Statistical analysis}

Results were expressed as the average plus/minus standard deviations. The data were analysed by two-factor analysis of variance (ANOVA) with repetitions and the means separated using the $\mathrm{LSD}$ test at $\mathrm{p}=0.05$. Regression analysis was performed using Statistica 9 software.

\section{Results and discussions}

Effect of different preparation methods on total phenolic content and antioxidant capacity in Phyllostachysflexuosa

Fig. 1 shows that higher TP values were measured in fresh shoots, compared to boiled or pickled shoots. Significantly 
66

different, the highest value of $1,227.6 \pm 75.5 \mu \mathrm{g} \mathrm{GA} / \mathrm{ml}$ for TP was measured in the case of fresh shoots, which also gave similarly the highest measured value of $154.0 \pm 13.8 \mu \mathrm{g} \mathrm{AA} / \mathrm{ml}$ ) in the case of AC compared to boiled or pickled shoots. The second highest TP (21\% lower than fresh shoots) and AC values (22\% lower than fresh shoots) were measured in the case of boiled shoots $(964.5 \pm 44.9 \mu \mathrm{g} \mathrm{GA} / \mathrm{ml}$ and $120.1 \pm 11.2 \mu \mathrm{g} \mathrm{AA} / \mathrm{ml})$, and both parameters were significantly higher than values measured in pickled shoots. Significantly, the lowest TP (65 and 55\% lower than fresh or boiled shoots respectively) and AC (93 and 91\% lower than fresh or boiled shoots) values were measured in the case of pickled shoots $(431.7 \pm 44.5 \mu \mathrm{gGA} / \mathrm{ml}$ and $10.4 \pm 1.6 \mu \mathrm{g}$ $\mathrm{AA} / \mathrm{ml})$. The obtained results are comparable to those of Zhang et al. (2011) who have also found that compared to fresh shoots, boiled bamboo shoots had 10\% and 23\% lower TP and AC values respectively. Chung and Kim (2009) have examined the antioxidant activities of garlic (Allium sativum L.) stems and garlic bulbs according to processing methods and have also found the lowest total phenolic content and antioxidant activity in pickles. The same was true for pickled Agaricus bisporous compared to the fresh product (Ganguli et al., 2007).

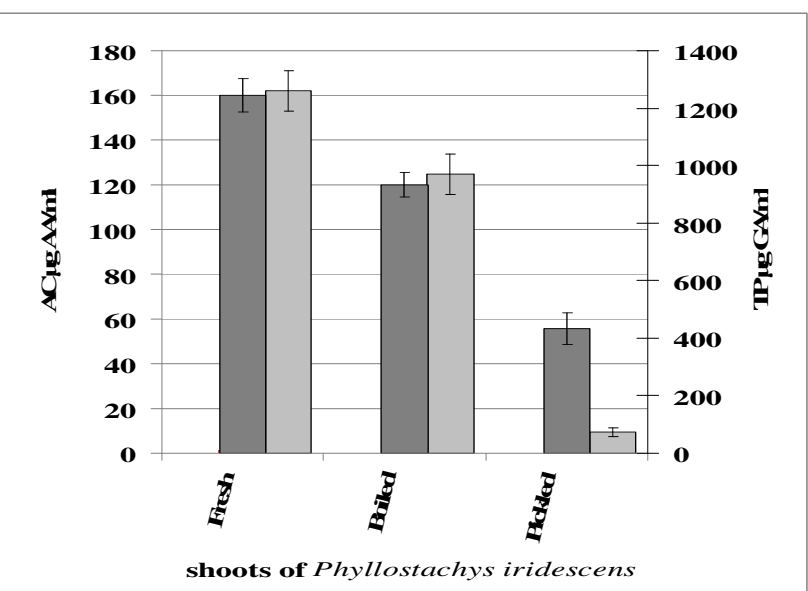

Fig. 1. Total phenolics content (TP) $(\mu \mathrm{g} \mathrm{GA} / \mathrm{ml})$ and antioxidant capacity (AC) $(\mu \mathrm{g} \mathrm{AA} / \mathrm{ml})$ of fresh, boiled and pickled shoot extracts of Phyllostachys flexuosa $(\mathrm{n}=4, \pm \mathrm{SD})$. White and grey columns refer to antioxidant capacity and total phenolic content, respectively

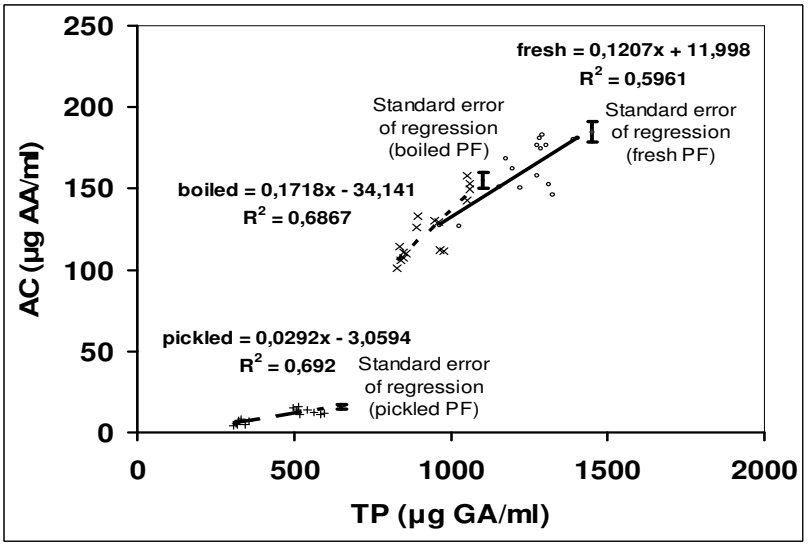

Fig. 2. Correlation between total antioxidant capacity $(\mathrm{AC})(\mu \mathrm{g} \mathrm{AA} / \mathrm{ml})$ and total phenolic content $(\mathrm{TP})(\mu \mathrm{gGA} / \mathrm{ml})$ in fresh, boiled and pickled shoots of Phyllostachys flexuosa $(\mathrm{p}=0.01)$. Solid, dotted and dashed lines refer to fresh (o), boiled $(\mathrm{X})$ and pickled $(+)$ shoots respectively
Since total antioxidant capacity and total phenolic content followed a similar trend (Fig. 1) in fresh, boiled and pickled shoots of Phyllostachys flexuosa, it was investigated the correlation between $\mathrm{AC}$ and TP with the different processing methods. There was a significant correlation $(p=0.01)$ between $A C$ and TP values in all cases, as shown in Fig. 2. These correlation results were in agreement with those of Park and Jhon (2010), Zhang et al. (2011) and Li et al. (2013) who have also found a significant correlation between bamboo shoot total phenolics content and antioxidant activity.

\section{Total phenolic content and antioxidant capacity in the shoots of different Phyllostachys taxa}

\section{Totalphenolic content}

The results regarding total phenolic content are shown in Fig. 3 for all Phyllostachys taxa. The highest values of TP were measured in the case of $P$. aureosulcata $(1,321.95 \pm 74.49 \mu \mathrm{g}$ $\mathrm{GA} / \mathrm{ml}), P$. flexuosa $(1,306.05 \pm 65.25 \mu \mathrm{g} \mathrm{GA} / \mathrm{ml}, 1 \%$ lower than PA) and $P$. violascens $(1,270.51 \pm 12.89 \mu \mathrm{g} \mathrm{GA} / \mathrm{ml}, 4 \%$ lower than PA), but the difference between these was not significant. The fourth highest value was measured in $P$. iridescens $(1,217.96 \pm 26.02 \mu \mathrm{g} \mathrm{GA} / \mathrm{ml}, 8 \%$ lower than PA) which was significantly lower than the previous taxa. The fifth highest value characterized $P$. aureosulcata $\mathrm{f}$. aureocaulis $(1,208.74 \pm 50.63 \mu \mathrm{g}$ GA $/ \mathrm{ml}$, 9\% lower than PA), closely followed by $P$. viridiglaucescens $(1,203.84 \pm 92.78 \mu \mathrm{g} \mathrm{GA} / \mathrm{ml}, 9 \%$ lower than PA) and P. bissetii $(1,193.81 \pm 14.35 \mu \mathrm{g} \mathrm{GA} / \mathrm{ml}, 10 \%$ lower than PA) and P. aureosulcata f. spectabilis $(1,187.77 \pm 101.31 \mu \mathrm{g}$ $\mathrm{GA} / \mathrm{ml}, 10 \%$ lower than PA). The difference between these taxa was not significant. The ninth highest value was obtained from $P$. nigra var. nigra $(1178.17 \pm 69.45 \mu \mathrm{g} \mathrm{GA} / \mathrm{ml}, 11 \%$ lower than PA) followed by $P$. nigra var. henonis $(1,130.49 \pm 66.45 \mu \mathrm{g}$ $\mathrm{GA} / \mathrm{ml}, 15 \%$ lower than PA). There was no significant difference between PNN and PNH and neither previous taxa except for PA, PF and PVI. The next lower value was that of $P$. mannii $(1,082.41 \pm 93.39 \mu \mathrm{g} \mathrm{GA} / \mathrm{ml}, 18 \%$ lower than PA) which was significantly lower only than the first four. The next lowest value was measured in $P$. humilis (983.18 $\pm 33.66 \mu \mathrm{g}$ $\mathrm{GA} / \mathrm{ml}, 26 \%$ lower than PA) which was significantly lower than all previous taxa except for PM. The next lowest TP value was given by $P$. sulphurea var. sulphurea $(970.14 \pm 62.69 \mu \mathrm{g} \mathrm{GA} / \mathrm{ml}$, $27 \%$ lower than PA) which was significantly lower than all previous taxa except for PM and PH. The lowest value of TP was measured in $P$. vivax f. aureocaulis $(826.22 \pm 64.75 \mu \mathrm{g} \mathrm{GA} / \mathrm{ml}$, $38 \%$ lower than PA) which was significantly lower than TP contents in all other taxa. The obtained results are in agreement with those of Jin and Yuan (2012) and Li et al. (2013) who have also found that $P$. aureosulcata $\mathrm{f}$. spectabilis is a species which contains high levels of flavonoids and phenolic acids, but they used ethanolic extracts in their experiments. There is no comparative study of TP in the above Phyllostachys species shoots in the available literature, except for that of Jin and Yuan (2012) who have made an intra-specific comparison of $P$. aureosulcata and $P$. edulis cultivars (forms).

\section{Total antioxidant capacity}

Results for AC in the case of all taxa are shown in Fig. 3. The highest values were obtained in the case of $P$. iridescens $(184.24 \pm$ $3.75 \mu \mathrm{g} \mathrm{AA} / \mathrm{ml}), P$. aureosulcata $(177.99 \pm 10.27 \mu \mathrm{g} \mathrm{AA} / \mathrm{ml}, 3 \%$ 


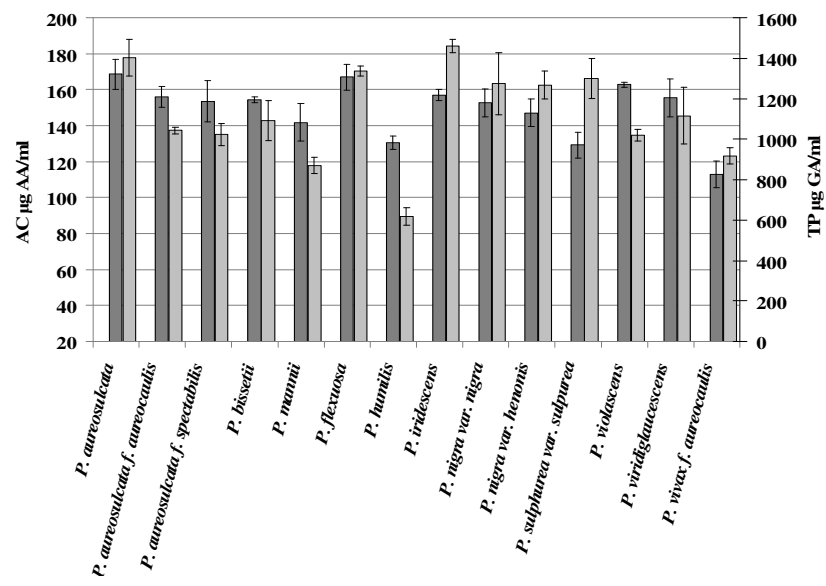

Fig. 3. Total phenolics content (TP) ( $\mu \mathrm{g} \mathrm{GA} / \mathrm{ml})$ and antioxidant capacity (AC) $(\mu \mathrm{g} \mathrm{AA} / \mathrm{ml})$ of shoot extracts of different Phyllostachys $\operatorname{taxa}(n=4, \pm S D)$. White and grey columns refer to antioxidant capacity and total phenolic content, respectively

lower than PI) and P. flexuosa $(170.42 \pm 3.06 \mu \mathrm{g} \mathrm{AA} / \mathrm{ml}, 8 \%$ lower than PI), but the difference between them was not significant. The fourth highest AC value was measured in $P$. sulphurea var. sulphurea $(166.18 \pm 11.09 \mu \mathrm{g} \mathrm{AA} / \mathrm{ml}, 10 \%$ lower than PI) which was significantly lower only than the first taxa. The fifth highest value was given by $P$. nigra var. nigra $(163.39 \pm$ $17.18 \mu \mathrm{g} \mathrm{AA} / \mathrm{ml}, 11 \%$ lower than PI), followed by $P$. nigra var. henonis $(162.73 \pm 7.87 \mu \mathrm{g} \mathrm{AA} / \mathrm{ml}, 11 \%$ lower than PI) and the difference was significant only compared to PI. The difference between the two $P$. nigra varieties was not significant. $P$. viridiglaucescens $(145.42 \pm 15.78 \mu \mathrm{g} \mathrm{AA} / \mathrm{ml}, 21 \%$ lower than PI) and P. bissetii $(142.93 \pm 10.97 \mu \mathrm{g} \mathrm{AA} / \mathrm{ml}, 23 \%$ lower than PI) produced the seventh and eighths highest values. There was no significant difference between the two taxa, whereas their values were significantly lower than the first 3 taxa. These were followed by $P$. aureosulcata f. aureocaulis $(137.45 \pm 1.93 \mu \mathrm{g} \mathrm{AA} / \mathrm{ml}, 25 \%$ lower than PI) and P. aureosulcata f. spectabilis (135.24 $\pm 6.16 \mu \mathrm{g}$ $\mathrm{AA} / \mathrm{ml}, 27 \%$ lower than PI), but there was no significant difference between the two $P$. aureosulcata forms, while they significantly differed from the first six taxa. The next lowest value of AC was measured in P. violascens $(134.77 \pm 3.22 \mu \mathrm{g} \mathrm{AA} / \mathrm{ml}$, $27 \%$ lower than PI) which was only significantly different from the first six taxa. P. vivax f. aureocaulis (123.15 $\pm 4.65 \mu \mathrm{g} \mathrm{AA} / \mathrm{ml}$, $33 \%$ lower than $\mathrm{PI}$ ) produced the next lowest $\mathrm{AC}$ value, which was significantly lower than all previous taxa. P. mannii (117.83 $\pm 4.57 \mu \mathrm{g} \mathrm{AA} / \mathrm{ml}, 36 \%$ lower than PI) gave the next lowest value and was significantly different from all previous taxa except for

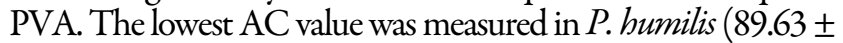
$4.94 \mu \mathrm{g} \mathrm{AA} / \mathrm{ml}, 51 \%$ lower than PI) which was significantly lower than all the other taxa. Phyllostachys aureosulcata was among the taxa producing the highest antioxidant capacity which is in agreement with the findings of Jin and Yuan (2012) and $\mathrm{Li}$ et al. (2013). In the available literature there is no comparative study of AC in the above Phyllostachys species shoots, except for the intra-specific comparison of $P$. aureosulcata and P. edulis forms (cultivars) by Jin and Yuan (2012).

The results of TP with AC in shoots of the different taxa were compared and regarding the measured values from the highest to the lowest, the taxa could not be ranked in the same order. This could possibly be explained by the fact that not only
TP constitutes to AC in bamboo shoots (Zhang et al., 2011), but there is possibly inter-specific differences in other phytochemical contents, including L-ascorbic acid (Park and Jhon, 2010; Zhang et al., 2011) and polysaccharides (Zhang et al., 2011), even though this has not been reported for Phyllostachys taxa and should be the target of further investigation.

\section{Influence of shoot phenology and temperature on total phenolic content}

Comparative study of total phenolics content in the above Phyllostachys species shoots has not been reported before. When comparing TP values of the different taxa shown and the initial harvest dates, the highest TP values were measured in the taxa harvested on the first collection date and the values consequently decrease in taxa collected at later harvest dates, with the lowest values in taxa collected at the last harvest date. Because of our findings that there was a clear decreasing trend in TP values measured in the successively later harvested bamboo taxa shoots, it was examined the possible environmental cause of this phenomenon. Since the plants were irrigated, it was assumed that water supply did not play a role in the phenomenon. Besides the obvious genetic differences between the taxa in the capacity of phenylpropanoid synthesis reported for other plants by Prohens et al. (2007) or other phytonutrients reported by Yuan et al. (2009), temperature seemed to be another factor which is known to influence the synthesis of phenolic compounds (Janda et al., 1999; Pál et al., 2013). Therefore, daily maximum and minimum temperature $\left({ }^{\circ} \mathrm{C}\right)$ values for the examined harvest period, from April to May, are shown on Fig. 4. During April daily maximum values (were between $+10{ }^{\circ} \mathrm{C}$ and $+23{ }^{\circ} \mathrm{C}$ ) started to rise one week prior to the first harvest date $\left(22^{\text {nd }}\right.$ of April), while daily minimum values (were between $+1{ }^{\circ} \mathrm{C}$ and $+6{ }^{\circ} \mathrm{C}$ ) did not alternate much and remained more or less constant. Maximum values (were between $+14^{\circ} \mathrm{C}$ and $+25^{\circ} \mathrm{C}$ ) levelled off with larger fluctuation between $23^{\text {rd }}$ of April to $10^{\text {th }}$ of May, while daily minimum values (were between $+5^{\circ} \mathrm{C}$ and +10 $\left.{ }^{\circ} \mathrm{C}\right)$ gradually increased until the second harvest date $\left(29^{\text {th }}\right.$ of April). Daily minimum and maximum values increased again during the days preceding the third harvest $\left(13^{\text {th }}\right.$ of May). From the $17^{\text {th }}$ of May temperatures started to rise again and the highest daily minimum and maximum temperatures $\left(+15^{\circ} \mathrm{C}\right.$ and +29 ${ }^{\circ} \mathrm{C}$ respectively) were recorded during the last week of May. Generally, either the daily minimum or daily maximum temperature ranges rose gradually between the harvest dates, during the examined April-May period. None of the previous reports (Jin and Yuan, 2012) monitored environmental parameters and their possible effects on phytonutrient content of bamboo shoots in the examined Phyllostachys taxa. Thus, examining reports on other plants, the current results could be explained by the findings of $\mathrm{Oh}$ et al. (2009) who have found that low temperatures caused an increase in total phenolics content in lettuce. The same was reported by Zobayed et al. (2005) for Hypericum perforatum. Also Ni et al. (2013) found that in leaves of bamboo Indocalamus latifolius, altitudinal variation also caused an increase in total phenolic and flavonoid contents and antioxidant activity. Our findings suggested that besides the genetic influence on the capacity of phenylpropanoid biosynthesis and on specific shooting times of bamboo taxa, the earlier harvest date through the influence of lower temperatures could enhance the phytochemical content of bamboo shoots intended as vegetables. But further intra-specific experiments, 
68

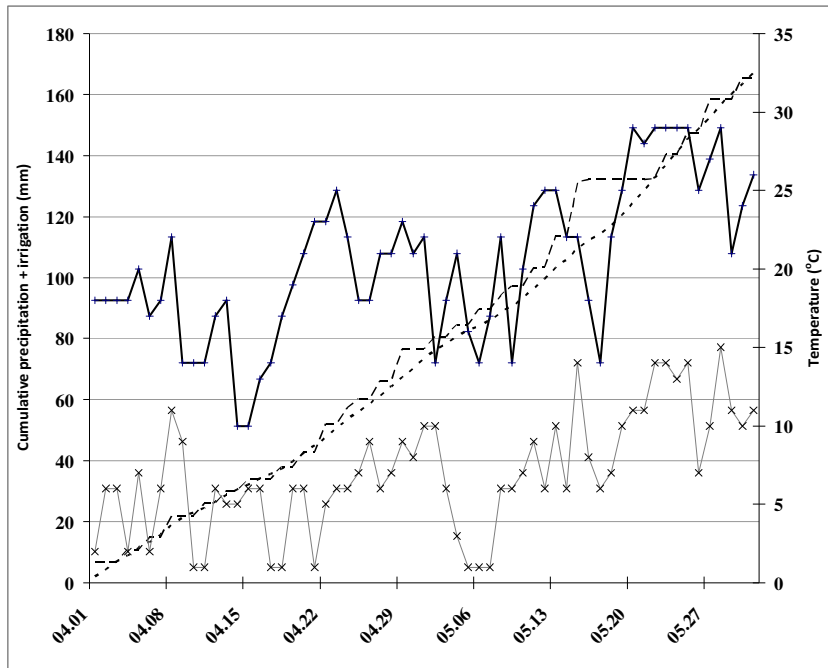

Fig. 4. Change of daily minimum, maximum air temperature $\left({ }^{\circ} \mathrm{C}\right)$, cumulative precipitation plus irrigation $(\mathrm{mm})$ and cumulative potential evapotranspiration ( $\mathrm{mm}$ ) during the harvest period (April-May). Grey line $(\mathrm{X})$, black line $(+)$, dotted line, dashed line represents minimum temperature, maximum temperature, cumulative potential evapotranspiration, cumulative precipitation plus irrigation respectively

involving more frequent harvest dates with regards to phytochemical content of bamboo shoots, need to be carried out to underline this.

\section{Conclusions}

When comparing the processing methods, the highest TP and AC values were obtained in the case of fresh shoots of Phyllostachys iridescens compared to boiled or pickled shoots, while the lowest TP and AC values were measured in the case of pickled shoots. There was a significant correlation $(p=0.01)$ between AC and TP values in fresh, boiled and pickled shoots of PF. The inter-/intra-specific comparison showed that the highest TP and AC were measured in the case of PA, PF, PVI, PI and PI, PA, PF, PSS, respectively. The highest TP values were measured in taxa harvested on the first collection date and the values subsequently decreased in taxa collected at later harvest dates. Based on the current findings, it can be concluded that besides the genetic factors influencing shoot phenology and capacity of phenylpropanoid biosynthesis, through the influence of lower temperatures the earlier harvest date possibly also influenced the phytochemical content of bamboo shoots.

\section{Acknowledgements}

This work was supported by Kutató Kari Kiválósági Támogatás - Research Centre of Excellence9878/2015/FEKUT and KTIA_AIK_12-1-2012-0012 and OTKA K84290 projects. Attila Hegedüs acknowledges a János Bolyai Scholarship, Hungarian Academy of Sciences.

\section{References}

Benzie IFF, Strain JJ (1996). The ferric reducing ability of plasma (FRAP) as a measure of "antioxidant power": the FRAP assay. Anal Biochem 239(1):70-76.
Chae BS, Kim DK, Eun JS, Kwon GS, Shin TY (2010). The inhibitory effect of bamboo culm extract on the development of pulmonary inflammation in pristane-induced lupus mice. Nat Product Sci 16(4):245-250.

Cho H, Cho KA, Jia S, Cho SJ, Choi D (2009). Influence of bamboo oil supplementation on blood lipid concentration in serum. J Ind Eng Chem 15(2):281-284.

Choi D, Cho KA, Na MS, Choi HS, Kim YO, Lim DH, Cho SJ, Cho $\mathrm{H}$ (2008). Effect of bamboo oil on antioxidative activity and nitrite scavenging activity. J Ind Eng Chem 14(6):765770.

Chongtham N, Bisht MS, Haorongbam S (2011). Nutritional properties of bamboo shoots: Potential and prospects for utilization as a health food. Compr Rev Food Sci F 10(3):153169.

Choudry D, Sahu JK, Sharma GD (2012). Value addition to bamboo shoots: a review. J Food Sci Tech 49(4):407-414.

Chung JY, Kim CS (2009). Antioxidant activities of domestic garlic (Allium sativum L.) stems and garlic bulbs according to cooking methods. J Korean Soc Food Sci Nutr 38(2):188-194.

Ganguli A, Ghosh M, Singh N (2007). Antioxidant activities and total phenolics of pickles produced from the edible mushroom, Agaricus bisporous. J Cul Sci Tech 5(2-3):131-142.

Ham I, Yang G, Lee J, Lee KJ, Choi HY (2009). Hypolipidemic effect of $\mathrm{MeOH}$ extract of Bambusae Caulis in Taeniam in hyperlipidemia induced by Triton WR-1339 and high cholesterol diet in rats. Immunopharm Immunot 31(3):439445.

Helyes L, Neményi A, Pék Z, Berki M, Daood HG (2013). Effect of variety and water supply on phytochemical (phenolics and carotenoids) content and composition of processing tomato. Acta Hort 971:93-98.

Helyes L, Varga Gy (1994). Irrigation demand of tomato according to the results of three decades. Acta Hort 376:323328.

Hong EJ, Jung EM, Lee GS, Kim JY, Na KJ, Park MJ, Kang HY, Choi KC, Seong YH, Choi IG, Jeung EB (2010). Protective effects of the pyrolyzates derived from bamboo against neuronal damage and hematoaggregation. J Ethnopharmacol 128(3):594-599.

Hungarian Meteorological Service (2011). Temperature forecast of Gödöllő. 31 May. 2011. <http://www.met.hu/idojaras/elorejelzes>

Janda T, Szalai G, Tari I, Páldi E (1999). Hydroponic treatment with salicylic acid decreases the effects of chilling injury in maize (Zea mays L.) plants. Planta 208(2):175-180.

Jin Y, Yuan K (2012). Studies on the functional components and bioactivity and the relativity of bamboo shoots and shells. Appl Mech Mater 108:314-319.

Kim DC, Cho E, In MJ, Oh CH, Hong KW, Kwon SC, Chae HJ (2012). The prediction of shelf-life of pickle processed from maengjong bamboo. J Korean Acad-Ind Coop Soc 13(6):2641-2647.

Kim HJ, Kang MA, Kim SH, Yim SH, Lee IS (2011). Bioactive phenolic constituents from the culms of Phyllostachys 
bambusoides. Nat Prod Sci 17(4):267-272.

Kim JS, Kim MJ, Park MH, Ryu BM, Moon GS (2008). Angiotensin converting enzyme inhibition and antihypertensive effects of Phyllostachys pubescens culm extracts in spontaneously hypertensive rats. J Korean Soc Food Sci Nutr 37(1):27-34.

Kim SM, Jeon JS, Kang SW, Kim WR, Lee KD, Um BH (2012). Composition analysis and antioxidant activity of ojuk (Phyllostachys nigra Munro) leaf tea and shoot tea. J Appl Biol Chem 55(2):95-101.

Kleinhenz V, Midmore D (2001). Aspects of bamboo agronomy. Adv Agron 74:99-146.

Kweon MH, Hwang HJ, Sung HC (2003). Isolation and characterization of anticomplementary $\beta$-glucans from the shoots of bamboo Phyllostachys edulis. Planta Med 69(1):5662.

Lee MJ, Kim MJ, Song YS, Song YO, Moon GS (2008). Bamboo culm extract supplementation elevates HDL-cholesterol and ameliorates oxidative stress in C57BL/6 mice fed atherogenic diet. J Med Food 11(1):69-77.

Lee SK, Park JH, Kim BJ, Kim YT, Kim MN, Lim YY, Hong YJ, An JH, Byun HJ, Hwang JS (2010). A study on the antimicrobial effect of bamboo (Phyllostachys bambusoides) essential oil on Malassezia. Korean J Med Mycology 15(1):111.

Li YX, Cheng FR, Jin YC, Yuan K (2013). Studies on the active components and antioxidant activity of the extracts from different parts of bamboo. Asian J Chem 25(11):6354-6360.

Lu B, Liu L, Zhen X, Wu X, Zhang Y (2010). Anti-tumor activity of triterpenoid-rich extract from bamboo shavings (Caulis bambusae in Taeniam) Afr J Biotechnol 9(38):6430-6436.

Lu B, Ren Y, Zhang Y, Gong J (2009). Effects of genetic variability, parts and seasons on the sterol content and composition in bamboo shoots. Food Chem 112(4):10161021.

Ni Q, Wang Z, Xu G, Gao Q, Yang D, Morimatsu F, Zhang Y (2013). Altitudinal variation of antioxidant components and capability in Indocalamus latifolius (Keng) McClure leaf. J Nutr Sci Vitaminol 59(4):336-342.

Oh M-M, Carey EE, Rajashekar CB (2009). Environmental stresses induce health-promoting phytochemicals in lettuce. Plant Physiol Bioch 47(7):578-583.

Ohrnberger D (2002). Bamboos of the world: Annotated nomenclature and literature of the species and higher and lower taxa. $1^{\text {st }}$ Ed Elsevier Science BV, Amsterdam, 596 p.

Pál M, Gondor OK, Janda T (2013). Role of salicylic acid in acclimation to low temperature. Acta Agron Hung 61(2):161172.
Park EJ, Jhon DY (2009). Effects of bamboo shoot consumption on lipid profiles and bowel function in healthy young women. Nutrition 25(7-8):723-728.

Park EJ, Jhon DY (2010). The antioxidant, angiotensin converting enzyme inhibition activity, and phenolic compounds of bamboo shoot extracts. Food Sci Technol 43(4):655-659.

Park KH, Lee MW (2012). Anti-oxidative, anti-inflamatory and whitening effects of phenolic compounds from Bambusae Caulis in Liquamen. Nat Prod Res 26(18):1687-1691.

Prohens J, Rodríguez-Burruezo A, Raigón MD, Nuez F (2007). Total phenolic concentration and browning susceptibility in a collection of different varietal types and hybrids of eggplant: implications for breeding for higher nutritional quality and reduced browning. J Am Soc Hortic Sci 132(5):638-646.

Qi XF, Kim DH, Yoon YS, Li JH, Jin D, Deung YK, Lee KJ (2009). Effects of Bambusae caulis in Liquamen on the development of atopic dermatitis-like skin lesions in hairless mice. J Ethnopharmacol 123(2):195-200.

Ra J, Lee S, Kim HJ, Jang YP, Ahn H, Kim J (2010). Bambusae Caulis in Taeniam extract reduces ovalbumin-induced airway inflammation and $\mathrm{T}$ helper 2 responses in mice. $\mathrm{J}$ Ethnopharmacol 128(1):241-247.

Singleton VL, Rossi JA (1965). Colometry of total phenolics with phosphomolibdic-phosphotungstic acid reagents. Am J Enol Viticult 161(3):144-158.

Yoo MJ, Chung HJ (1999). Chemical properties of bamboo shoots and their changes of chemical components during the manufacture of pickles. Korean J Food Nutr 12(6):575-581.

Yuan JL, Gao ZM, Ma NX, Li XP, Yuan N, Wu LQ (2009). Nutritional composition and its genetic variance of Phyllostachys iridescens shoots. For Res 22(6):779-783.

Zhang JJ, Ji R, Hu YQ, Chen JC, Ye XQ (2011). Effect of three cooking methods on nutrient components and antioxidant capacities of bamboo shoot (Phyllostachys praecox C.D. Chu et C.S. Chao). Journal of Zhejiang University Science 12(9):752759.

Zhang Z, Wang X, Yu S, Zhao M (2011). Isolation and antioxidant activities of polysaccharides extracted from shoots of Phyllostachys edulis (Carr.). Int J Biol Macromol 49(4):454457.

Zobayed SMA, Afreen F, Kozai T (2005). Temperature stress can alter the photosynthetic efficiency and secondary metabolite concentration in St. John's wort. Plant Physiol Bioch 43(1011):977-984. 